\title{
Correlation between Interpersonal Communication Motive and Interpersonal Communication Gratification with Psychological Well Being of Media Digital user in Indonesian Millennial Generation
}

\author{
S W Astuti ${ }^{1}$, A Bajari ${ }^{2}$, A Rachmiatie ${ }^{3}$, A Venus ${ }^{4}$ \\ 1,2,3,4 Doctorate Program of Communication, Faculty of Communication, Padjadjaran \\ University, Bandung, Indonesia \\ ${ }^{1}$ sri.wahyuning.astuti@mercubuana.ac.id, ${ }^{2}$ atwarbajari@gmail.com, \\ 3atierachmiatie@yahoo.com, ㅅantervenus@gmail.com
}

\begin{abstract}
This research is trying to find out correlation between selection of communication motive and interpersonal communication gratification with Psychological Well Being of digital media user in millennial generation. Picturing interpersonal communication gratification and Psychological Well Being in millenial generation will also be describe in this research. Subject in this research is millenial generation in Senior High School in South Jakarta whose age is 15-19 year[1] .Data is taken by using Scale of interpersonal communication consists of 27 items (Rubin R. P., 1988[2]), and Scale of relationship communication gratification consists of 18 items (Hecht M. , (1978a)) [3] and scale of Psychological Well Being consists of 54 items [4]. To calculate data in this research by using SEM analysis. Besides to see the corrrelation between the two variables, also to find out correlation perdimension of each research scale.

Keywords: Interpersonal Communication Gratification, Motive Of Communication, Psychological Well Being .
\end{abstract}

\section{INTRODUCTION}

Being the largest population in the world, millenial has become the most interesting focus of discussion, their behavior in common or certain characteristics of their behavior. Indonesia Indonesia as the country with the population 265 million, has percentage of millenial generation until 50 percent[5]. Data from Statistics Center Bureu stated that the number of Indonesia population in the age 14-34 year (age range of millenial generation) achieved 136 million. From the number, in the average they do not interact by using conventional media but using digital media. The number of active media user is 143,26 million[6]. From the number, almost $50 \%$ is millenial generation utilizing the use of social media. Using social media by millenial generation makes their interpersonal communication pattern is also changing, does not use face to face communication anymore but through digital. Tapscot (2013) in [7] stated that millenial generation has become the generation which has poor interpersonal communication.

Lacking ability of millenial in doing interpersonal communication is caused by the changing of communication pattern. Previous communication using direct face to face now is 
subtituted by technology[8]. Although the use of technology is considered make communication easier, it has the effect on communication gratification for millenials[9]. Level of communication gratification is closedly related with the picture of quality of someone's life. Ryff dan Singer (2007) and Ryff C. \&., 2007[10]) stated that individual's ability to actively maintain positive relationship with other people through interpersonal relationship is the same important as the individual's physical health[11].

The effect of interpersonal relationship gratification with someone's Psychological Well Being has been proved, those who have positive interpersonal relationship tend to have Psychological Well Being in the high level. (Barnett, Kibria, Baruch, \& Pleck, 1991; Black \& Pedro-Carroll,1993; Bogard, 2005; Videon, 2005)[12]. Individual with good interpersonal relationship is one characteristics of maturity[13]. They are able to love and conduct interpersonal relationship built with the foundation of mutual trust. The individual also has strong feeling of empathy and affection to other human, has deep friendship and good identification with other people. The individual also has intimacy with other people and is able to give guidance and leadership to others (generativity). Those characteristics is very important for mental health[14].

Milennials who spend the time with digital world, become interesting object to study in determining their communication motives. Besides changing of communication pattern, motives to do communication in the middle of more massively technological usage becomes the other reason to explore more deeply about the motives of millennials in doing interpersonal communication. This research has theoretical purpose and practical purpose. Theoritical purpose of this research is to find out correlation between motive of interpersonal communication with communication gratification and Psychological Well Being of the millenials. While practical purpose of this research is to find out model for increasing the well being of millenials through motive of interpersonal communication.

Therefore, based on the above theory, this reserach is trying to propose the hypothesis those are: (1) There is correlation between motive of interpersonal communication with communication gratification and Psychological Well Being of millennial generation.

(2) Communication motives of millennial will affect their communication gratification

(3) Communication gratification_of millennial will affect their Psychological Well Being

If explained conceptual model, motive of interpersonal communication is the independent variable, communication gratification is intermediary variable and Psychological Well Being is dependent variable.

FIGURE 1: Conceptual Model

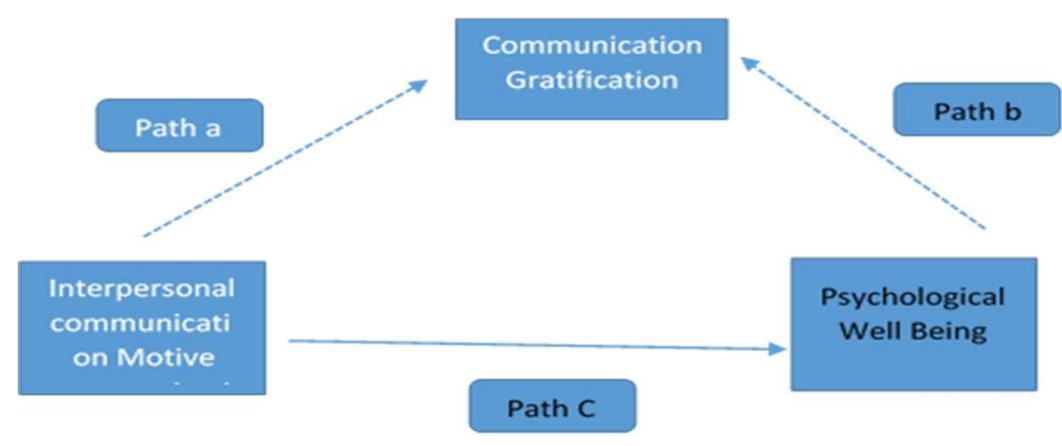




\section{RESEARCH METHOD}

This research is a quantitative research to test the correlation between communication motives with Psychological Well Being in millenial generation,and whether gratification in interpersonal communication affects the Psychological Well Being in millenial generation. Sample in the population is millenial generation in the Senior High School South Jakarta by using multi stage random sampel. From Senior High School in South Jakarta are selected 10 school swith the number of sample 969 people consists of 446 male students and 523 female students. The respondents' range of age is 14-18 years old. All students are users of digital media. This research used 3 measurement instruments, each of them to measure the variables studied. The three measurement tools are, Scale of communication motive by Rubin et al., 1988, mesauring why and how people do communication consists of 28 items, Scale of comunication gratification consists 19 item, and Scale of Psychological Well Being, consist 54 items or moderate version [13].

\section{RESULTS AND DISCUSSION}

After giving questionaire to 10 Senior Hhigh Schools in South Jakarta, was gained 969 respondents with distribution as follows:

TABLE 1: Demographic data of respondents

\begin{tabular}{llll}
\hline Descriptive & & frequency & Percentage \\
\hline Sex & Female & 523 & 54,0 \\
& Male & 446 & 46,0 \\
Age & 14 & 21 & 2,2 \\
& 15 & 263 & 27,1 \\
& 16 & 469 & 48,4 \\
& 17 & 193 & 19,9 \\
& 18 & 23 & 2,4
\end{tabular}

Based on the above data, number of respondents betweeen male and female has the range which is not too far, while from the age, millenial respondents mostly positioned in the range of 16 years old.

In the average millenials use smartphone with operational system android that is 655 persons, followed by using iphone 298 persons and the rest use two smartphones in the same time or or use blackberry.

The next result of analysis was done by using SEM, before was done Confirmatory Factor Analysis (CFA) to check validity and reliability of the test instrument. The next test is by using Fit test to see the fitting of the research model. Result of the test showed the score of RMSEA 0,056 and score of CMIN/df 4,069 in the category good fit. While the score of GFI, AGFI, NFI and CFI positioned in the range of marginal Fit (Table.3). From some fitting of model, model is said to be fit if at least one of the methods in testing the fitting of model is fulfilled. (Hair et al, 1998). In one empirical study, a researcher is not demanded to fulfill all criterias goodness 
of fit, but depends on the judgment of each researcher. Measurement of reliability also showed the items in this research are reliable with the score of reliability each for Psychological Well Being 0,981, Communication motive 0,975 and Communication gratification 0,973 (table 4)

TABLE 3: Score Goodnes of Fit

\begin{tabular}{llll}
\hline Fit Measures & Desired Value & Measurement Model & Structural Value \\
\hline$X^{2} / d f$ & Lebih dari 3 & 4,069 & 4,221 \\
GFI & $\geq 0,95$ & 0,685 & 0,691 \\
AGFI & $\geq 0,90$ & 0,669 & 0,675 \\
NFI & $\geq 0,90$ & 0,531 & 0,546 \\
CFI & $\geq 0,95$ & 0,599 & 0,610 \\
RMSEA & $\leq 0,08$ & 0,056 & 0,058 \\
\hline
\end{tabular}

TABLE 4: Reliability

\begin{tabular}{lll}
\hline & CR & AVE \\
\hline Psychological Well Being & 0,981 & 0,970 \\
Communication motive & 0,975 & 0,959 \\
Communication gratification & 0,973 & 0,941 \\
\hline
\end{tabular}

TABLE 5: Correlation of latent variabel

\begin{tabular}{llll}
\hline & $\begin{array}{l}\text { Communication } \\
\text { motive }\end{array}$ & $\begin{array}{l}\text { Communication } \\
\text { gratification }\end{array}$ & $\begin{array}{l}\text { Psychological Well } \\
\text { Being }\end{array}$ \\
\hline Communication motive & 1 & & \\
Communication gratification &, 425 & 1 & 1 \\
PWB &, 242 &, 444 & 1 \\
\hline
\end{tabular}

TABLE 6: Hypothesis Testing: Summary Result

\begin{tabular}{lllll}
\hline Hypotheses & Relationship Being Examined & Cooeficient & SE & P Value \\
\hline $\mathrm{H} 1_{\mathrm{a}}$ & $\begin{array}{l}\text { There is correlation between } \\
\text { Communication motive, with }\end{array}$ & 4,925 &, 395 & $* * *$ \\
& $\begin{array}{l}\text { communication gratification } \\
\mathrm{H} 1_{\mathrm{b}}\end{array}$ & & & \\
& $\begin{array}{l}\text { There is corelation between } \\
\text { Communcation motive with }\end{array}$ & 1,596 &, 043 &, 110 \\
& PWB
\end{tabular}




$\mathrm{H} 1_{\mathrm{c}}$ There is correlation between $\quad 5,325 \quad, 18 \quad * * *$
Communication gratification
with PWB

The next step is calculating the correlation between each variables and hypothesis testing. Based on calculation by using SEM, each variable correlates positively.. Millenials communication motive affects positively their communication gratification with the score of correlation 0,395 means that $39,5 \% \%$ millenial communication gratification is determined by their motive in doing communication (table 6). Besides that, picturing Psychological Well Being of millenials is also determined by their communication gratification. Although not having big score that is 0,180 or $18 \%$, the two variables have positive correlation. However, millenials' motive of communication does not have positive correlation with the picturing of millenials' PWB. Both variables have negative correlation.

This research is the first research in Indonesia which is trying to see correlation between communication motive and millenials' communication gratification with Psychological Well Being. Milennials as generation who have poor communication pattern and make use of most of the daily activities with digital world make them have poor communication pattern. This is because most of their time is togetherly used with smartphone so that changing the communication pattern. This research is trying to find out the picturing of communication motive chosen by millenials when doing communication. Motive of interpersonal communication is actually extension from gratification in using mass media. . It means that in choosing communication motive is adapted with the probability of gratification to be gained [15]. When millenial choose the motive in doing communication there is a wish for satisfaction to be gained. Result of the research revealed that there is correlation between choice of interpersonal communication motive with their communication gratification [11]. Individuals in this case who have satisfaction in their communication gratification, were reported to experience the increasing in their Psychological Well Being . Research conducted by Barnett et al., stated that female teenagers who have positive interpersonal relationship with the father also experience gratification in their communication so that it affects their Psychological Well Being [12] .

In accordance with result of the research, the researcher saw the importance of picturing the millenials' motive and communication gratification and in the same time saw the correlation with their Psychological Well Being. In Indonesia, millenial generation become the generation with the highest population. From 265 million of population in Indonesia [5] the number of millenials is half of the population. Bapenas stated milennials in Indonesia is almost 90 million [5]. While the range of age of milennials according to t Straus and Howe is ranging from 13 until 37 years old [1]. High number of millenials makes the generation who have high independence become interesting object and subject to observe. There are many researches targeted to millenials, starting from behavior in virtual world until real world, from politics until business. This thing is because big number of millenials and the difference in behavior with previous generation are interesting to study.

For millenial generation, the growth of Psychological Well Being is not only influenced by the real world but also by the virtual world. This happens because the life of millenials is not separated from digital technology. Extension of interaction space into digital of course brings the consequence for millenials. The desire to be the same with what is seen in 
digital world make the millenials experience decreasing in mental health. , one of them is easy to get anxiety, and unable to maintain relationship in the real world [16]. Mental health in Indonesia become problematic problems and has not got attention from the government. Based on the data from Riset Kesehatan Dasar (Riskesdas) 2013, prevalence of mental, emotional disturbance showed by the symptoms of depression and anxiety in millenial generation is recorded around 5 percent for the age of 15 years above or about 14 million people. [5]

This research results the finding with empirical proof tested, that is the first is there is significant correlation between motive of communication with millenial's communication gratification. It means that the reason someone do communication brings them into gratification in relation and communication. The next finding is interesting to consider is there is positive correlation between communication gratification with Psychological Well Being of millenial generation. This result is certainly complete the previous empirical proof that communication satisfaction affects the positive relationship with other people which become one indicator of Psychological Well Being.

However, choice of interpersonal communication motive is in fact does not have positive correlation with Psychological Well Being of millenials. This unpositive correlation is because some other indicators in communication motive, have opposite meanings. Some dimensions of interpersonal communication motive has positive correlation with Psychological Well Being ,that is in the dimension of inclusion and love has positive correlation with dimension of positive relationship with other people in the Psychological Well Being .

\section{CONCLUSIONSS}

Based on the result of research described above, Psychological Well Being millenial is affected by their gratification in doing communication. And the level of communication gratification is affected by how the choosing of motive in doing communication. The higher level their gratification in doing communication, the higher their Psychological Well Being of millenials. And also how millenials choose the motive in doing interpersonal communication will affect their communication gratification. .

\section{REFERENCES}

[1] N. Howe, "Retrieved from Forbes.Com: https://www.forbes.com/sites/neilhowe/2014/10/27/introducing-the-homelandgeneration-part-1-of-2/," Forbes Media LLC., 2014. [Online]. Available: https://www.forbes.com/sites/neilhowe/2014/10/27/introducing-the-homelandgeneration-part-1-of-2/. [Accessed: 29-Aug-2019].

[2] R. B. Rubin, E. M. Perse, and C. Barbato, "Conceptualization and Measurement of Interpersonal Communication Motives,” Hum. Commun. Res., vol. 14, no. 4, pp. $602-$ $628,1988$.

[3] P. J. Hecth, M. L., \& Marston, "Communication satisfaction and the temporal development of conversations.," Commun. Res. Reports, vol. 4, no. (2), pp. 60-65., 1987.

[4] Ryff, "The structure of psychological well being revisited .," J. Pers. Soc. Psychol., vol. 69, no. 4, pp. 719-727., 1995.

[5] BPS (Biro Pusat Statistik), "Statistik Gender Tematik: Profil Generasi Milenial Indonesia.," Jakarta, 2018.

[6] Asosiasi Penyelenggara Jasa Internet Indonesia, "Penetrasi dan Perilaku Pengguna 
Internet di Indonesia, Survei 2016.," 2016. [Online]. Available:

https://www.apjii.or.id/survei2016.

[7] Y. . Putra, "Teori Perbedaan Generasi," Among Makarti, pp. 123-134, 2016.

[8] J. L. Hartman and J. Mccambridge, "COMMUNICATION STYLES," vol. 74, no. 1, pp. 22-44, 2011.

[9] C. T. Judy C Pearson, Anna Carmon, "Motives for Communication: Why the Millenial generation Uses Electronic Devices," J. Commun. Speech Theatr. Assoc.

North Dakota, vol. 22, 2010.

[10] C. D. Ryff and B. Singer, "What to do about positive and negative items in studies of psychological well-being and ill-being? [5]," Psychother. Psychosom., vol. 76, no. 1, pp. 61-62, 2006.

[11] C. V. Heeman, "Interpersonal communication motives, satisfaction, and psychological well being in father-young adult daughter relationships. .," 2008.

[12] R. G. Barnett, "Adult daughter-parents relationship and their associations with dauhgters' subjective well-being and psychological distres. Journal of Marriage and Family.," J. Marriage Fam., vol. 53 (1), pp. 29-42., 1991.

[13] P. S. \& L. Hati, "How 's Indonesian Candidate Migrant Worker' s Social Support and Psychological Well-being In Real Life ?,” vol. 219, no. Icpc, 2018.

[14] C. D. Ryff, "Psychological Well-Being Revisited : Advances in the Science and Practice of Eudaimonia," vol. 53706, pp. 10-28, 2014.

[15] A. M. Rubin and R. B. Rubin, "Interface of personal and mediated communication: A research agenda," Crit. Stud. Mass Commun., vol. 2, no. 1, pp. 36-53, 1985.

[16] S. W. Astuti, "Efek Psikologis Penggunaan Content dan Media Konvergensi Smartphone Pada Mahasiswa Efek Psikologis Penggunaan Content dan Media Konvergensi Smartphone Pada Mahasiswa," no. 2, pp. 18-35, 2018. 